\title{
Rapid shifts in a marine fish assemblage follow fluctuations in winter sea conditions
}

\author{
Miguel Henriques ${ }^{1,2}$, Emanuel J. Gonçalves ${ }^{1, *}$, Vítor C. Almada ${ }^{1}$ \\ ${ }^{1}$ Eco-Ethology Research Unit, Instituto Superior de Psicologia Aplicada, R. Jardim do Tabaco 34, 1149-041 Lisboa, Portugal \\ ${ }^{2}$ Parque Natural da Arrábida, Instituto da Conservação da Natureza, Praça da República, 2900 Setúbal, Portugal
}

\begin{abstract}
Patterns of interannual variation are described for an inshore fish assemblage off the Arrábida rocky coast (Portugal). During an 11 yr period, the fish assemblage showed pronounced changes especially within its tropical, warm-temperate and cold-temperate elements. These changes followed a fluctuating pattern connected with the North Atlantic Oscillation (NAO) with a series of years where the modifications were slight, interspersed with years where faunal changes were very rapid, affecting up to $35 \%$ of the total number of species recorded in those years. After a transition year from a cold to a warm period or vice versa, the majority of the newcomers from the preceding phase were eliminated. Winter conditions, but not summer conditions, were good predictors of the observed patterns. Increases in sea surface temperature (SST) were associated with increases in the proportions of tropical and warm-temperate fish and with decreases in the proportion of cold-temperate elements, the reverse being true for decreases in SST. Interannual variation in faunal composition was not simply a consequence of changes in SST. Changes in other factors such as current flow direction and transport mechanisms, capable of bringing fishes from different biogeographical sources, may also play a role in the observed patterns. The influence of the NAO is therefore not only mediated by its effects on SST but also by the changes it induces in wind and current patterns along the Portuguese shore. Long-term trends caused by persistent changes, like those involving global warming, may be masked by the fact that at an intermediate time scale, faunal changes are characterised by a succession of oscillations rather than by a steady modification in a single direction. This outlines the importance of long-term monitoring data, since short-term studies may only capture single phases of a complex oscillation, giving a false picture of the overall pattern of change.
\end{abstract}

KEY WORDS: Faunal changes · Portugal - North Atlantic Oscillation · NAO · Sea surface temperature · SST $\cdot$ Wind stress $\cdot$ Temperate fish assemblage

\section{INTRODUCTION}

Global warming consequences are stimulating an increasing research effort to study the responses of marine fauna and flora to changes in sea surface temperature (SST) (Beaugrand et al. 2002, Schiel et al. 2004). Several pioneering studies encompassing several decades of the last century have unambiguously demonstrated that inshore fish assemblages, as well as those of other taxa, displayed clear shifts associated with long-term patterns of sea temperature changes (Southward et al. 1995). These temperature changes in the sea follow quite complicated processes that are only gradually being understood (Speth \& Kohne 1983, Levitus et al. 2000, Jones et al. 2001, Ottersen et al. 2001). Within the course of a century there may be several warming and cooling periods, spanning several decades each. This has been documented, for example, in British waters where a cooling trend was detected up to about 1930, followed by a warming phase that lasted until about the late 1950s, a new cooling phase that persisted until the early 1980 s, and a new warming phase that apparently still persists in the north-east Atlantic and is expected to last at least for the first decades of this century (Paeth et al. 1999, Hawkins et al. 2003, Woehrling et al. 2005). 
Superimposed on these long-term oscillations, there are other shifts in SST that last for shorter periods of less than a decade and are mostly related to the North Atlantic Oscillation (NAO) (Hurrell 1995, Rodwell et al. 1999, Ottersen et al. 2001, Saunders \& Qian 2002, Hurrell et al. 2003). This NAO seems to be particularly active during the winter (Rodwell et al. 1999) and may be quantified by the difference in atmospheric pressure between a high pressure zone located at mid latitudes and a low pressure zone located at higher latitudes (Hurrell et al. 2003). The Azores high pressure zone and the Iceland low pressure zone are typical points of reference to quantify the NAO index (Hurrell 1995), although other pairs of locations are also frequently used (Rogers 1984, Jones et al. 1997).

On a year-to-year basis, there may be rapid changes in SST, for instance when there is a change from a period of consecutive years of positive NAO to a period when the NAO becomes negative, as was the case of the 1996 winter along western European shores (Kushmir 1999, Greene \& Pershing 2003). In this region, much of the short-term SST variation seems to be strongly influenced by the NAO (Wanner et al. 2001, Hurrell et al. 2003). In years where the NAO is strongly positive, storms crossing the Atlantic travel through northwest Europe. In the British Isles and adjacent areas, southwest winds become prominent, winters are mild and rainy and SST tends to be relatively higher. In contrast, in southwest Europe and in the Mediterranean, winters are sunny, dry and cold, and northern winds tend to be prominent. SST is relatively lower, as water transported from the south and southwest does not reach the shore and upwelling events may even occur, further cooling nearshore waters. In years of negative NAO, the situation is much the reverse. The storm track is displaced to the south, meaning that southwest Europe and the Mediterranean receive considerable amounts of rain, warmer southwest winds become prominent and SST tends to be higher. In these same years, northwest Europe experiences extremes of cold air and water temperature and fewer storms (for a comprehensive overview of NAO impacts, see Hurrell et al. 2003).

The plurality of time scales of SST changes is one of the main confounding factors in the analysis of global warming consequences in the marine environment, since a perceived persistent trend toward increasing temperatures may sometimes, when viewed at a broader time scale, turn out to be a temporary phase of an oscillation. For marine biologists, however, these oscillations provide excellent 'natural experiments' that can tell us much about the ways marine fauna and flora respond to fluctuations in SST and other oceanographic variables. These oscillations range from phenomena that span several decades (Hawkins et al.
2003) to shorter cycles like those associated with the NAO (Atrill \& Power 2002). Even abrupt interannual changes in sea conditions may substantially affect fish assemblages, especially in areas that are at or near biogeographical barriers, where faunas adapted to waters of different temperatures come into contact. For instance, in Baja California, Thomson \& Lehner (1976) stated that cold water events in the winter could, in some years, temporarily but drastically affect the tropical and subtropical components of the littoral ichthyofauna.

In 1996, an exceptional year marked by an abrupt transition from a series of positive NAO years to a very negative one, the effects of this short-term climatic shift could be detected in a variety of groups of marine animals around western Europe (Stenseth et al. 2002). An 11 yr (1992-2002) study on the interannual fluctuations in the composition of an inshore fish assemblage at Arrábida (western Portugal) is presented here. During this survey, 2 warm periods interspersed with cold periods were detected, which gave us the opportunity to assess the magnitude and patterns of ichthyofaunal changes that followed these rapid shifts in oceanographic conditions.

\section{MATERIALS AND METHODS}

Study area. The Arrábida Marine Park between Cape Espichel $\left(38^{\circ} 25^{\prime} \mathrm{N}, 9^{\circ} 13^{\prime} \mathrm{W}\right)$ and Portinho da Arrábida $\left(38^{\circ} 29^{\prime} \mathrm{N}, 8^{\circ} 58^{\prime} \mathrm{W}\right)$ on the west Portuguese shore (Fig. 1) constituted the study area. Most of this area faces south, being protected from the prevailing north and northwest winds by the adjacent mountain chain of Arrábida. The coast is very steep, and the intertidal zone consists mainly of rocky cliffs, small beaches and several areas covered by boulders. The rocky subtidal extends offshore for some tens of metres, and to depths of less than $15 \mathrm{~m}$ (except at Cape Espichel, where it reaches more than $30 \mathrm{~m}$ ). Boulders of many different sizes resulting from the erosion of the nearby calcareous cliffs increase habitat complexity. Following this narrow band of rocks and boulders are sandy bottoms with very gentle slopes.

During the summer, the prevailing north and northwest winds on the Portuguese west shore cause frequent upwelling events, which often keep nearshore waters cooler than offshore waters at the same latitude. Surface currents tend to flow to the south and southwest. During the winter, the prevailing conditions vary considerably depending on the intensity and the sign of the NAO. Typically, poleward surface circulation prevails, which is particularly enhanced in years when the NAO is predominantly negative, promoting south and southwest winds and an increase in 


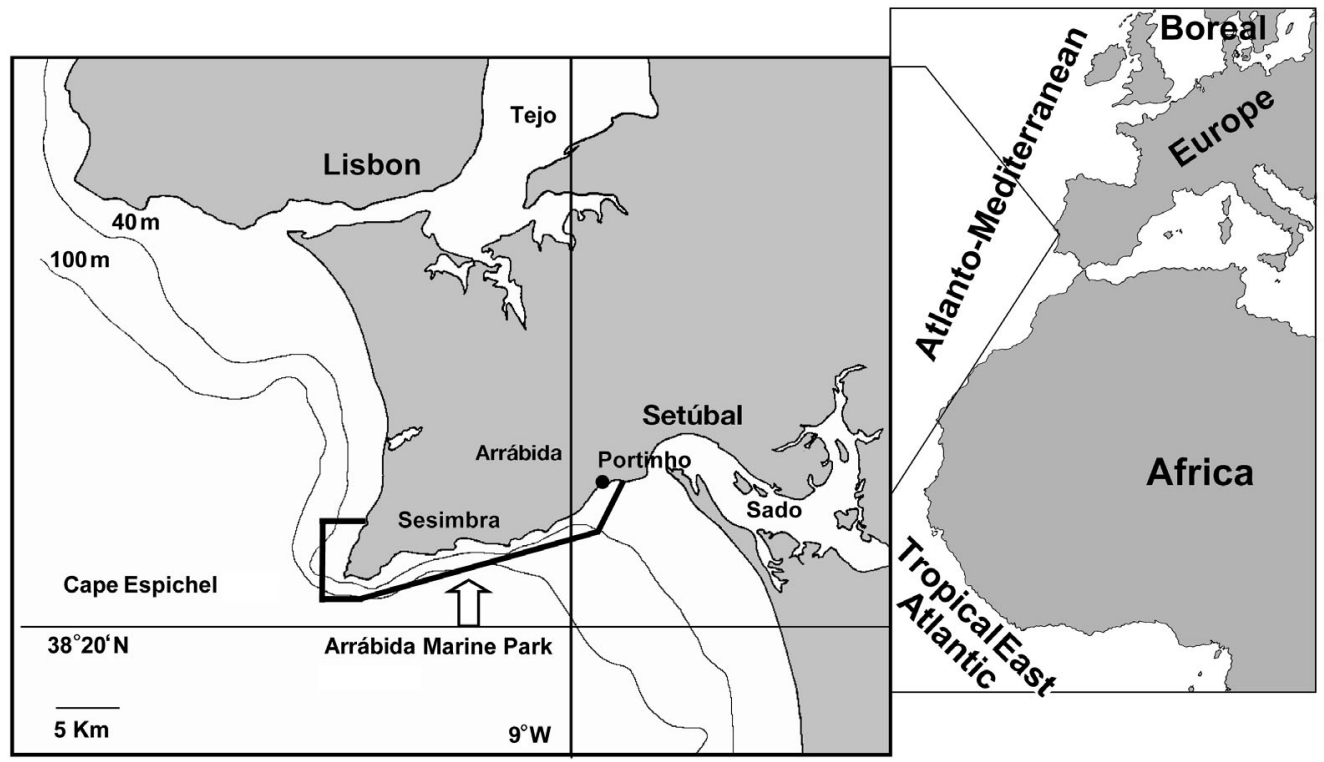

Fig. 1. Study area (Arrábida Marine Park) on the west coast of Portugal. Right panel shows main biogeographic provinces of the north-east Atlantic

SST. However, these conditions are reversed in winters of positive NAO, with the prevailing northern winds being sufficiently strong to disrupt the poleward water movement along the shore. They can even promote winter upwelling events. These 2 factors link winters of positive NAO to lower values of SST. A detailed characterisation of the oceanography of the area can be found in Fiúza et al. (1982), Fiúza (1983), Martins et al. (2002), Bischof et al. (2003) and Peliz et al. (2005).

Data collection. Data were collected from May 1992 to December 2002 by scuba diving. Dives were distributed uniformly among all months in each year, with a few exceptions in the winter when the sea was very rough. More than 320 dives were undertaken. Each dive lasted $1 \mathrm{~h}$ and followed a regular path beginning on the sandy bottom, $10 \mathrm{~m}$ off the rocky substrate, and ending on the shore. All habitats, including sand, bedrock and boulders were inspected in a similar way during all dives. These visual inspections included searching crevices, holes and spaces beneath stones to detect cryptic fish species, as well as surveying the water column. The annual mean number of dives was 29.6 (min. $=13, \max .=60, \mathrm{SD}=29.6)$. Since each dive lasted $1 \mathrm{~h}$, the number of dives corresponds to the number of observation hours per year. The aim of the surveys was to compile an inventory of all fish species detected in the study area for each year. Thus, for the purpose of this study, no attempts at estimating abundances were undertaken, and each species was counted only once for each year. For each dive, only the species spotted for the first time in that year were added to the annual list. Whenever possible, the pres- ence of juveniles presumed to be young-of-the-year was recorded. Since different fish species grow at very different rates in their first year of life, fish were ascribed to this category based on the authors' own experience of following the recruitment phase of these coastal fish species, as well as on the published information for each species.

SST data and information on wind direction and intensity were based on ICOADS (International Comprehensive Ocean-Atmosphere Data Set, available at: www.cdc.noaa.gov/coads/), using cells of $1^{\circ}$ latitude and longitude $\left(38^{\circ} \mathrm{N}, 10^{\circ} \mathrm{W}\right)$. NAO data were obtained from the Climate Analysis Section, National Center for Climate Research (NCAR), Boulder, Colorado, USA, available at: www.cgd.ucar.edu/cas/jhurrell/. Since our goal was to study the influence of regional sea conditions on the coastal fish assemblages, the choice of SST and wind data from a larger scale data set was considered a better option than using field measurements at the study site since these are influenced by local conditions.

Classification of the ichthyofauna. All fish species were classified according to their distribution in the following groups of biogeographic affinity. Tropical: species that range from tropical west Africa (Tropical East Atlantic, Fig. 1) to the entrance of the Mediterranean or the south of the Iberian Peninsula; warmtemperate: species that occur from the Mediterranean and north-western coasts of Africa to the western entrance of the English Channel; cold-temperate: species that have their southern limit at or near the Atlantic coast of the Iberian Peninsula and extend in range into the North Sea or even farther north; temper- 
ate: species that are present in the whole temperate Atlanto-Mediterranean region, i.e. they occur from Mauritania to the North Sea, and also in the Mediterranean but not in tropical Africa.

Very eurythermal species that range from the tropical Atlantic to boreal areas, and oceanic fish that are only accidentally found nearshore, were excluded since they do not provide any information useful to this type of study. In the case of Ammodytidae n. id., the species of the genera Ammodytes and Gymnamodytes could not be distinguished visually during the dives. As they differ in ecology and distribution, we excluded them from the analyses. The gobiesocids Lepadogaster lepadogaster and L. purpurea were considered to be the same species until 2002 (Henriques et al. 2002) and were therefore recorded as $L$. lepadogaster. Appendix 1 presents the list of all fish species and their respective group of biogeographic affinity as defined above. The information on species distributions was based on Whitehead et al. (1984, 1986), Quéro et al. (1990) and Froese \& Pauly (2006) (FishBase) with updates presented by Henriques et al. (1999, 2002).

Data analysis. To reduce redundancy and dimensionality, the oceanographic variables were subjected to a principal components analysis (PCA), followed by a varimax rotation. The faunistic data, comprising the number of species of each biogeographic category, were also independently subjected to a PCA. After identification of the relevant components of oceanographic and faunistic data sets, the relationships among them were analysed using non-parametric Kendall's tau correlations. To control for the possibility that interannual variation in observation time could affect the results, the number of species of each category was also expressed as a percentage of the total number of species in that year, and the relationships between faunistic and oceanographic variables were again analysed using non-parametric Kendall's tau correlations. To objectively test if years were grouped in cold and warm periods regardless of oceanographic information and without biogeographical criteria, multidimensional scaling (MDS) was performed on the similarity matrix of all $11 \mathrm{yr}$. Similarities were computed using Sorenson's index. To identify whether differences between warm and cold years were significant, an analysis of similarities (ANOSIM) test was used (462 permutations). ANOSIM analysis was performed with the PRIMER 5 programme. All other statistical analyses were performed with STATISTICA 6 (StatSoft).

\section{RESULTS}

During the $11 \mathrm{yr}$ of this work, a total of 115 coastal fish species were recorded in the study area. Of these, 106 were included in the analysis. Thirty-two species were present in all years, with an additional 7 species present in all but one year. However, in spite of this permanent group, there was a considerable amount of variation in the fish assemblage between consecutive years. These interannual fluctuations were noticeable both in the total number of species recorded in each year, and in the contributions of each biogeographic group (Fig. 2). The mean number of fish species recorded per year was $63.4(\min .=52, \max .=75, \mathrm{SD}=$ 7.4), while the corresponding figures for the percent contributions of the different biogeographic groups were: tropical $($ mean $=11.4, \min .=7.3, \max .=18.1$, $\mathrm{SD}=3.3)$; warm-temperate $($ mean $=44.7$, $\min .=40.9$, max. $=49.2, \mathrm{SD}=3.0)$; cold-temperate $($ mean $=11.7$, min. $=5.6, \max .=16.4, \mathrm{SD}=3.6) ;$ and temperate $($ mean $=32.2, \min .=28.8, \max .=36.5, \mathrm{SD}=2.4)$.

Even with 18 new species added to the faunal list in the 1996-1998 warming period, the cumulative number of species detected in the study area was already $79 \%$ after 4 yr of sampling (49\% in the first year), and no correlation between the number of recorded species in each year and observation time for that year was found (Kendall's tau correlation $=0.09, \mathrm{p}=0.69$, $\mathrm{n}=11$ ). These facts give us confidence that the year-toyear variations detected represent real changes in assemblage structure and are not an artifact caused by variations in the number of observation hours between years.

The oceanographic and climatic parameters used in our study are presented in Fig. 3. A PCA performed on these parameters showed that the first 2 principal com-

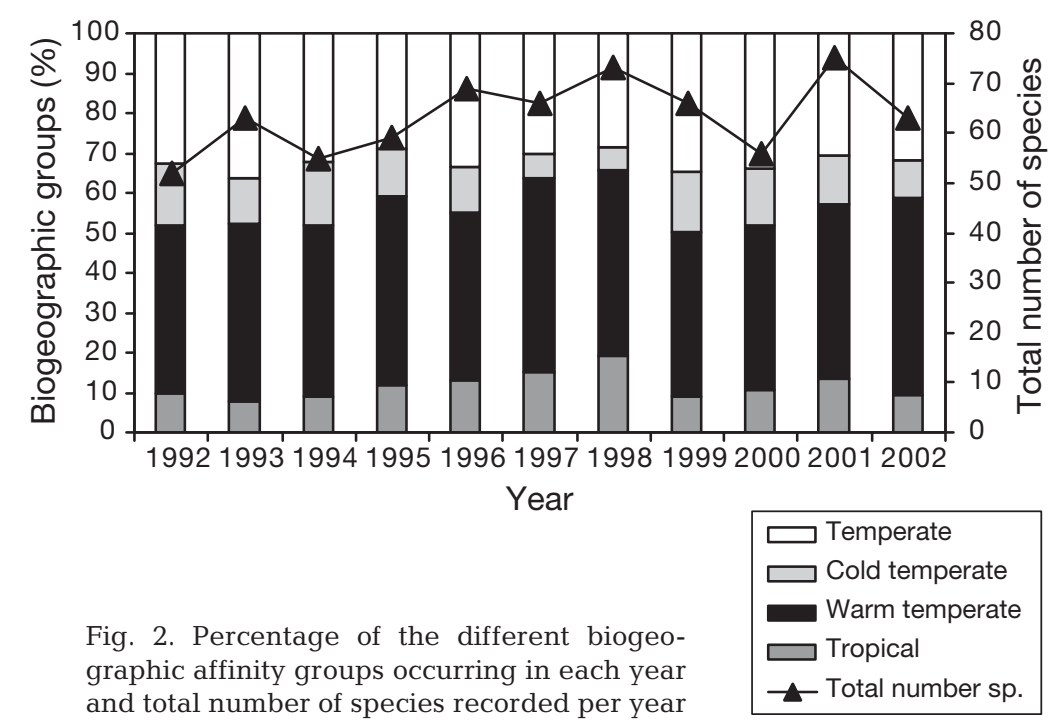



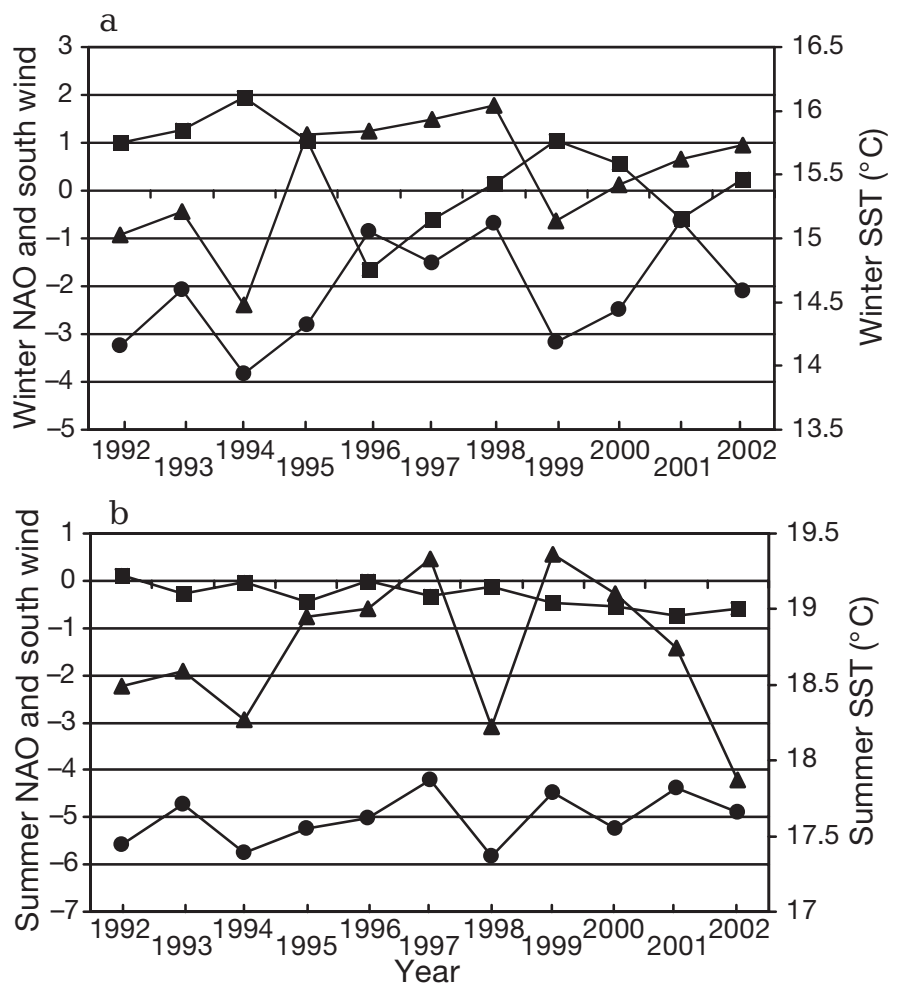

Fig. 3. Oceanographic and climatic parameters used in this study. (a) Winter conditions, from December of the previous year to April. (b) Summer conditions, from June to September. NAO (ם): North Atlantic Oscillation index; SST (ム): sea surface temperature (mean ${ }^{\circ} \mathrm{C}$ value for the grid $38-39^{\circ} \mathrm{N}$ : $\left.9-10^{\circ} \mathrm{W}\right)$; and south wind $(\bullet)$ : southward wind for the same grid (minus sign indicates that the net wind is northwards)

ponents explained $76 \%$ of the variance and can be interpreted as representing winter and summer conditions, respectively (Fig. 4a). Winter SST, amount of winter south wind and, at the opposite end of the axis, winter NAO were associated with the first principal component, PC1, while summer conditions were clearly associated with PC2. This observation indicates that summer and winter conditions are poorly correlated and that instead of speaking of warm and cold years, different seasons (winter and summer) must be analysed separately.

A PCA applied to the faunistic data is presented in Fig. 5a. When inspecting the factor loadings of the 2 components retained in the analysis, it becomes apparent that PC1 contains a group of close relationships involving the tropical and warm-temperate biogeographic affinity groups on one end and the cold-temperate group, with an opposite sign, on the other end. Interestingly, the temperate group is almost entirely associated with the second axis, indicating that its pattern of interannual variation is poorly correlated with the other groups. Moreover, the warm and cold periods derived from the factor scores of the oceanographic and cli- matic PCA (Fig. 4b), are also apparent in the factor scores of the faunistic data (Fig. 5b). The only discrepancy involves the 1996 to 1998 warm period, which, according to faunistic criteria, was initiated in 1995.

To evaluate to what extent an objective analysis based on the faunal similarities between years, regardless of any biogeographic classification, recovered the same separation between cold and warm years, MDS was performed (Fig. 6a). Similarities among years were computed based on Sorenson's index, which only considers presence-absence data regardless of any previous classification of the species. Although considerable scattering is apparent, the cold years are clearly grouped on one side of the $x$-axis and the warm years on the other. One-way ANOSIM revealed that differ-
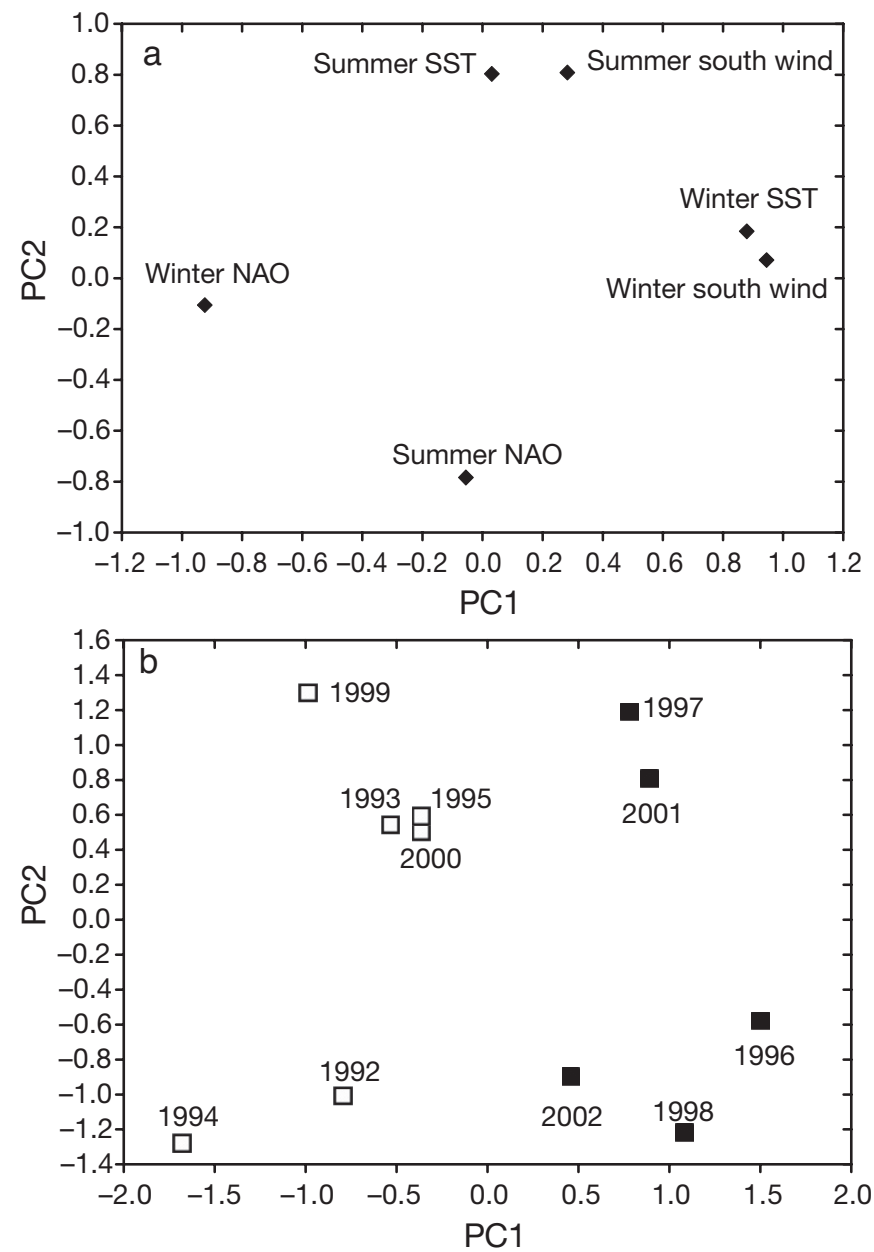

Fig. 4. Principal axis factor analysis of the 6 oceanographic and climatic parameters displayed in Fig. 3. (a) Principal components; (b) factor scores: cold years ( $\square$ ), warm years (ם). The first principal component (PC1) expresses winter conditions while the second principal component (PC2) expresses summer conditions. Factor loadings are varimax normalised. Determinant of correlation matrix: -2.1258. Eigenvalues: 2.987 (PC1) and 1.585 (PC2); \% total variance: 49.78 (PC1) and 26.42 (PC2) 


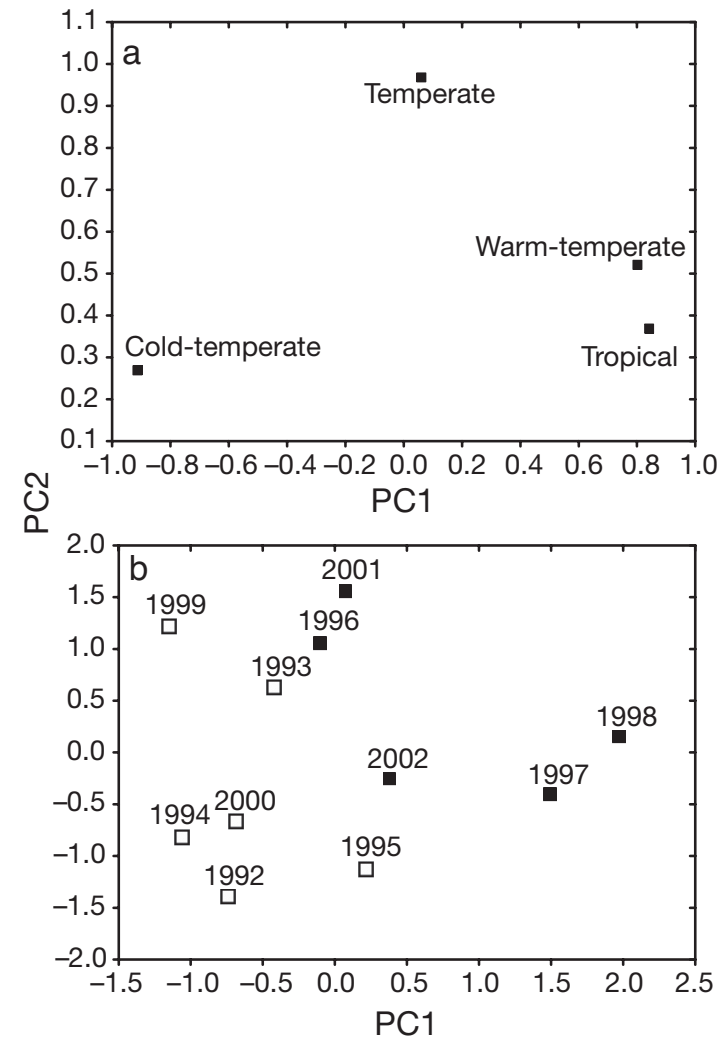

Fig. 5. Principal axis factor analysis of the 4 biogeographic affinity groups shown in Fig. 2. (a) Principal components; (b) factor scores: cold years $(\square)$, warm years (ם). Factor loadings are varimax normalised. Determinant of correlation matrix: -0.9851. Eigenvalues: 2.463 (PC1) and 1.131 (PC2); \% total variance: 61.57 (PC1) and 28.28 (PC2)

ences between these 2 groups were significant (Global $\mathrm{R}=0.46, \mathrm{p}=0.004$ ).

Looking at Sorenson's similarity values between consecutive years, 2 main changes in assemblage composition (shown by a reduction in similarity) are evident: one between 1995 and 1996 and a second one between 2000-2001 and 2001-2002 (Fig. 6b).

Kendall's tau correlations between the 2 principal components derived from the PCA on oceanographic conditions and the 2 components derived from faunistic data showed the following patterns. There was a significant correlation between winter conditions and the component that involves tropical, warm-temperate and cold-temperate groups $(r=0.60, p=0.01)$. This correlation was still significant after Bonferroni correction for multiple testing. The temperate group, on the other hand, was not correlated with winter conditions $(\mathrm{r}=0.35, \mathrm{p}=0.14)$. Summer conditions were not correlated with either faunistic variables $(r=0.02, p=0.94$ for the tropical, warm-temperate and cold-temperate groups; and $r=0.13, p=0.59$ for the temperate group). These data show that the tropical, warm-temperate and cold-temperate faunal groups co-vary with winter conditions, with warm-temperate and tropical species following a similar trend, while the cold-temperate fish follow an inverse relationship.

It could be argued that summer conditions would have an effect on the assemblage only in the autumn and winter, i.e. only on a fraction of the time sampled per year. On the other hand, the effects of winter conditions would be more easily captured because these are felt throughout the year and therefore many more dives would be needed to detect their possible effects on the fish fauna. However, correlations of the PC1 of faunistic data (tropical, warm-temperate and coldtemperate groups) with summer conditions of the previous year also yielded non-significant results and low correlation coefficients (data not shown).

The limited number of data points restricts the interpretation of correlations between the proportion of species of each biogeographic group and the physical parameters ascribed to winter conditions on the PCA of the oceanographic and climatic parameters. Nevertheless, after Bonferroni correction for multiple testing, a number of correlations remained significant (Table 1).
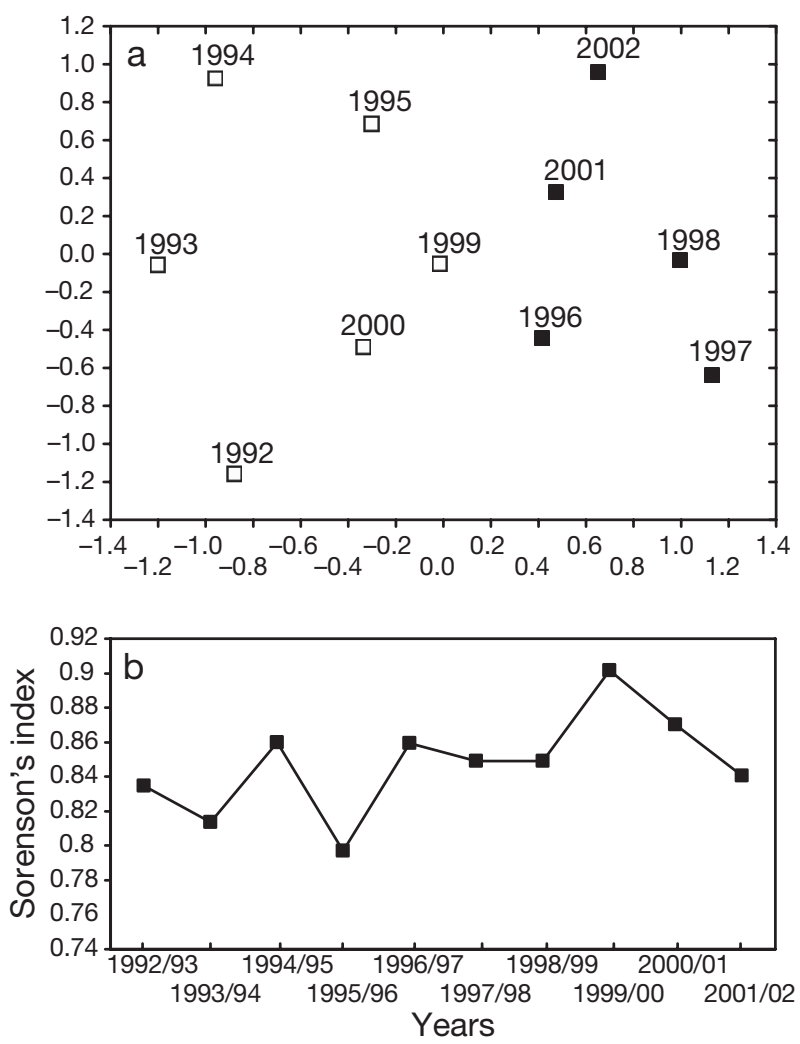

Fig. 6. Multidimensional scaling (MDS) on the similarity matrix (based on Sorenson's index) of all 11 yr. (a) MDS plot: cold years ( $\square$ ), warm years (ם); (b) Sorenson's index between consecutive years. A reduction in similarity reveals changes in the assemblage composition 
Table 1. Values of non-parametric Kendall's tau significant correlations (at $\mathrm{p}<0.05$ after Bonferroni correction) between the total number of species and the proportion of species of each biogeographic group and the physical parameters associated with winter conditions (PC1 in Fig. 4a). NAO: North Atlantic Oscillation Index; SST: sea surface temperature; ns: $\mathrm{p}>0.05$

\begin{tabular}{|lccc|}
\hline & $\begin{array}{c}\text { Winter } \\
\text { NAO }\end{array}$ & $\begin{array}{c}\text { Winter south } \\
\text { wind }\end{array}$ & $\begin{array}{c}\text { Winter } \\
\text { SST }\end{array}$ \\
\hline Total number of species & $\mathrm{ns}$ & 0.86 & 0.63 \\
Tropical and warm- & $\mathrm{ns}$ & $\mathrm{ns}$ & 0.83 \\
temperate & & & \\
Cold-temperate & $\mathrm{ns}$ & -0.73 & -0.82 \\
Temperate & $\mathrm{ns}$ & $\mathrm{ns}$ & $\mathrm{ns}$ \\
\hline
\end{tabular}

The total number of species was highly correlated with the amount of south wind during the winter as well as with winter SST, while tropical and warm-temperate fish taken together were highly correlated with winter SST. Negative significant correlations were found between the cold-temperate group and winter conditions (SST and south wind). As expected, the temperate group presented no significant correlations with any of the considered variables.

A number of interesting patterns arose when analysing the temporal patterns of occurrence for the set of species that changed markedly at the onset of the first warm period (1996 to 1998), either because they appeared for the first time in the survey (or were only sporadically detected before this period) or ceased to be recorded during this period (Table 2). These patterns were as follows: (1) only 1 species belonged to the temperate group, the others being classified as tropical (5 species), warm-temperate (6 species) or cold-temperate (5 species); (2) during the period 1996 to 1998 , the tropical and warm-temperate species increased gradually, each warm winter bringing new additions that remained present in the area until the end of 1998; (3) some of the newcomers were observed breeding in the area, and many cases of very small juveniles, likely locally produced, were recorded; (4) the end of the 1996 to 1998 warm period led to an almost complete disappearance of the warm water newcomers with a single species remaining in the area by the end of 1999 ( 2 other species had been observed very sporadically at the beginning of that year); (5) the cold-temperate group of species disappeared entirely in this period but recovered almost completely after a single cold winter; (6) during the second transition from cold to warm winters, this process was repeated, although on a smaller scale, with all warm water species reappearing in this second warm period being a subset of those found in the 1996 to 1998 warm period.

\section{DISCUSSION}

In the present study, several periods with little change were interspersed with years when faunal changes were remarkably high. Indeed, in years that marked transitions from cold to warm periods and vice versa, faunal changes could reach considerably high

Table 2. Temporal patterns of occurrence of the set of species that changed markedly at the onset of the first warm period (1996-1998) with indication of their biogeographic affinity group. WT: warm temperate; TR: tropical; CT: cold temperate; T: temperate; A: common occurrence of adults; J: common occurrence of juveniles; -: single or extremely sporadic occurrence. The 1996-1998 and 2001-2002 warm periods are in bold

\begin{tabular}{|c|c|c|c|c|c|c|c|c|c|c|c|c|}
\hline Biogeographic group & Species & 1992 & 1993 & 1994 & 1995 & 1996 & 1997 & 1998 & 1999 & 2000 & 2001 & 2002 \\
\hline \multirow[t]{6}{*}{ WT } & Phycis phycis & & & & & A & A & A & & & A & A \\
\hline & Serranus atricauda & & & & & & & JA & A- & & AJ & $\mathrm{A}$ \\
\hline & Serranus hepatus & & & & $\mathrm{J}_{-}$ & $\mathrm{J}$ & $\mathrm{J}$ & $\mathrm{J}$ & & & $\mathrm{J}$ & $\mathrm{J}$ \\
\hline & Diplodus bellottii & & & & & & & $\mathrm{J}$ & & & & $\mathrm{J}$ \\
\hline & Spicara maena & & & & & & $\mathrm{J}$ & & & & & \\
\hline & Pomatoschistus marmoratus & & & & & & JA & JA & JA & JA & JA & JA \\
\hline \multirow[t]{5}{*}{ TR } & Diplodus puntazzo & & & & A- & JA & JA & JA & & & JA & A \\
\hline & Oblada melanura & A- & & & & A & JA & JA & A- & & JA & A \\
\hline & Bothus podas podas & & & & & & & $\mathrm{J}$ & & & & \\
\hline & Synaptura lusitanica & & & & & & & A & & & & \\
\hline & Sphoeroides marmoratus & & & & & & & A & & & & \\
\hline \multirow[t]{5}{*}{ CT } & Ciliata mustela & JA & & & JA & & & & JA & JA & & \\
\hline & Pollachius pollachius & JA & JA & JA & JA & & & & JA & JA & A- & \\
\hline & Entelurus aequoraeus & $\mathrm{A}$ & A & & & & & & $\mathrm{A}$ & $\mathrm{A}$ & A- & \\
\hline & Taurulus bubalis & & & $\mathrm{A}$ & $\mathrm{A}$ & & & & & & & \\
\hline & Zeugopterus puntactus & & $\mathrm{A}$ & $\mathrm{A}$ & A & & & & $\mathrm{A}$ & & A- & \\
\hline $\mathbf{T}$ & Syngnathus typhle & & JA & JA & & & & & JA & & & \\
\hline
\end{tabular}


values. In 1999, a cold year that followed a 3 yr warm period (1996 to 1998), the number of species that ceased to be recorded, added to the number of species that reappeared, totalled 23. This represents $35 \%$ of the total number of species recorded in that year. ANOSIM confirmed these patterns, revealing significant differences in assemblage composition between cold and warm years. Moreover, the comparison of Sorenson's similarity index between consecutive years showed 2 main changes in assemblage composition that are consistent with the 2 transitions from cold to warm periods detected during this study.

If the patterns detected in our work represent a general trend for some coastal fish assemblages (namely those located in important marine biogeographic transition zones), studies with time windows that are too short will very easily fail to capture these 'turning points', providing a falsely stable picture of the fish fauna.

These short-term temporal windows of major faunal changes have already been documented in previous studies. In particular, Thomson \& Lehner (1976), in a different ocean and a distinct climatic context, found that years with severe cold winters eliminated much of the tropical littoral fish fauna of Baja California.

The surface waters along the Portuguese shore are dominated by the Canary current, which brings a regular supply of cold water from the north (Bischof et al. 2003), and likely also brings eggs and young fish. In some years, namely if the NAO is positive, this current will prevail in all seasons. When the winter NAO is negative and strong, south and southwest winds become predominant, and this current may be temporarily reverted, being replaced by a poleward flow (Frouin et al. 1990). These oceanographic conditions seem to explain the temporal patterns of faunistic variation observed in this study. In particular, the probable role of the winter south wind, which emerged as an important factor correlated with the total number of species, regardless of their biogeographic affinities, seems to be explained by these conditions.

The reason why the amount of winter south wind affects the total number of species recorded in a given year is as yet unclear. Santos et al. (2001) showed that when strong northwest winds are intense during peak abundances of sardine eggs and larvae, offshore transport of young stages leads to poor recruitment in the following months. In our study area, several coastal fish species breed during the autumn and spring (authors' unpubl. data). Thus, the same process that couples recruitment intensity with wind direction for sardines could also operate on a much broader spectrum of coastal fish, with northwest winds favouring offshore transport and south winds promoting nearshore retention of eggs and larvae.
It is likely that in some winters, the interruption of the nearshore flow to the south, forced by strong south winds, will provide the only opportunity for the northward transport of fish eggs, larvae and even juveniles (for instance, those associated with rafting materials). In the remaining winters, as well as in the other seasons, the predominant north winds and southward flowing currents will most likely bring fish from higher latitudes, a situation that would explain why, for the coldtemperate fish group, water temperature is a better predictor of change than wind direction. This is corroborated by a recent review of the winter upper ocean circulation in the western Iberian Basin by Peliz et al. (2005), who identified a particularly intense poleward flow along western Iberia in the years 1996 to 1998 and again in 2001 to 2002, whereas 1999 and 2000 did not show significant signatures of a poleward current. In contrast with this effect of winter south wind on species richness, high winter SST correlates with an increase in the proportion of fish of warm water affinity, and a decrease of the cold-temperate elements of the fish fauna.

How such an effect could be determined is as yet unknown. Studies of the relationships between the abundance of fish with different thermal preferences and oceanographic conditions have drawn attention to the diversity of causal mechanisms of change. While unusual drops in SST may kill warm water fish (Thomson \& Lehner 1976), Attrill \& Power (2002) illustrated a situation in which climatic oscillations exerted their effects on fish assemblages by affecting the suitability of estuarine nursery grounds for marine fish. These authors have shown for the first time that increases in the proportion of warm water fish in a given year were not necessarily caused by global warming. They found an increase in diversity during high NAO winters, which is partly explained by the increase in the number of rare species. Most of the additional species were those with a southern distribution. Based on these findings, they pointed out that: '...The appearance of unusual species or the extension of species' ranges have been used as indicators of climate change, but the appearance of warm-water southern species may simply reflect long-term climatic cycles...' (Attrill \& Power 2002, p. 277) Also, while some mobile species may engage in long range movements tracking water masses of adequate temperature, for many coastal benthic and benthopelagic fish species, recruitment and spawning opportunities will be affected by changes in SST and other oceanographic conditions. More work is necessary both to characterise patterns of faunal change and their linkages with oceanographic oscillations at different time scales, and also to understand the causal mechanisms through which fish assemblages are being affected by changing sea conditions. 
If our interpretation is correct, some changes that at first sight could be attributable to SST variation, may instead be caused by changes in other parameters, such as net changes in wind-driven flow direction, which are also correlated with changes in SST. The NAO is probably best viewed as a means of describing processes that operate at a higher level of control of oceanographic and atmospheric phenomena rather than as an agent that acts directly on the fish assemblages (for a critical review of the use of NAO and other climatic indices, see Stenseth et al. 2003). If this is the case, monitoring of fish assemblages needs to be accompanied by much more detailed surveys of oceanographic and meteorological variables, if we want to disentangle the relative contributions of the different candidate factors.

This view of temporal variations in fish assemblages as a series of oscillations will have important implications for the delimitation of what constitutes natural populations of fish. A given area may alternate between being a source and a sink of eggs, larvae and juveniles (Pulliam 1988), depending on the conditions in specific years and the mean duration of the surviving populations that are initiated by colonists arriving in a given episode of faunal change. While warm water fish may breed successfully in a given area during a long warm period, cold years may prevent those species from breeding or recruiting successfully in that same area.

Acknowledgements. Part of this study was supported by the Portuguese Science and Technology Foundation (Fundação para a Ciência e a Tecnologia, FCT) as part of the project POCTI/BSE/38350/2001 and through the Pluriannual and Programmatic funding schemes (R\&D Unit 331/94). The authors thank J. Martins for his assistance in the field and 2 anonymous referees for valuable comments and criticisms on the manuscript.

\section{LITERATURE CITED}

Attrill MJ, Power M (2002) Climatic influence on a marine fish assemblage. Nature 417:275-278

Beaugrand G, Reid PC, Ibañez F, Lindley JA, Edwards M (2002) Reorganization of North Atlantic marine copepod biodiversity and climate. Science 296:1692-1694

Bischof B, Mariano AJ, Ryan EH (2003) The Portugal current system. Available at: http://oceancurrents.rsmas.miami. edu/atlantic/portugal.html

Fiúza AFG (1983) Upwelling patterns off Portugal. In: Suess E, Thiede J (eds) Coastal upwelling, Part A. Plenum Publishing Corporation, New York, p 85-97

Fiúza AFG, Macedo ME, Guerreiro MR (1982) Climatological space and time variation of the Portuguese coastal upwelling. Oceanol Acta 5:31-40

Froese R, Pauly D (eds) (2006) FishBase. www.fishbase.org (version 07/2006)

Frouin R, Fiúza AFG, Ambar I, Boyd TJ (1990) Observations of a poleward surface current off the coasts of Portugal and Spain during winter. J Geophys Res 95:679-691
Greene CH, Pershing AJ (2003) The flip-side of the North Atlantic oscillation and modal shifts in slope-water circulation patterns. Limnol Oceanogr 48:319-322

Hawkins SJ, Southward AJ, Genner MJ (2003) Detection of environmental change in a marine ecosystem-evidence from the western English Channel. Sci Total Environ 310:245-256

Henriques M, Gonçalves EJ, Almada VC (1999) The conservation of littoral fish communities: a case study at Arrábida coast (Portugal). In: Almada VC, Oliveira RF, Gonçalves EJ (eds) Behaviour and conservation of littoral fishes. Instituto Superior de Psicologia Aplicada, Lisbon, p 473-519

Henriques M, Lourenço R, Almada F, Calado G, Gonçalves D, Guillemaud T, Cancela ML, Almada VC (2002) A revision of the status of Lepadogaster lepadogaster (Teleostei: Gobiesocidae): sympatric subspecies or a long misunderstood blend of species? Biol J Linn Soc 76:327-338

Hurrell JW (1995) Decadal trends in the North Atlantic Oscillation: regional temperatures and precipitation. Science 269:676-679

Hurrell JW, Kushnir Y, Ottersen G, Visbeck MH (2003) An overview of the North Atlantic Oscillation. In: Hurrell JW, Kushnir Y, Ottersen G, Visbeck MH (eds) The North Atlantic Oscillation, climatic significance and environmental impact. American Geophysical Union, Washington, DC, p 1-35

Jones PD, Jonsson T, Wheeler D (1997) Extension to the North Atlantic Oscillation using early instrumental pressure observations from Gibraltar and south-west Iceland. Int J Climatol 17:1433-1450

Jones PD, Osborn TJ, Briffa KR (2001) The evolution of climate over the last millennium. Science 292:662-667

Kushnir Y (1999) Europe's winter prospects. Nature 398: 289-291

Levitus S, Antonov JI, Boyer TP, Stephens C (2000) Warming of the world ocean. Science 287:2225-2229

Martins CS, Hamann M, Fiúza AFG (2002) Surface circulation in the eastern North Atlantic from drifters and altimetry. J Geophys Res 107:3217-3240

Ottersen G, Planque B, Belgrano A, Post E, Reid PC, Stenseth NC (2001) Ecological effects of the North Atlantic Oscillation. Oecologia 128:1-14

Paeth H, Hense A, Glowienka-Hense R, Voss R, Cubasch U (1999) The North Atlantic Oscillation as an indicator for greenhouse-gas induced regional climate change. Clim Dyn 15:953-960

Peliz A, Dubert J, Santos AMP, Oliveira PB, Le Cann B (2005) Winter upper ocean circulation in the Western Iberian Basin-fronts, eddies and poleward flows: an overview. Deep-Sea Res Part I 52:621-646

Pulliam HR (1988) Sources, sinks, and population regulation. Am Nat 132: 652-661

Quéro JC, Hureau JC, Karrer C, Post A, Saldanha L (eds) (1990) Check-list of the fishes of the eastern tropical Atlantic (CLOFETA), Vol I-III. JNICT, Lisbon; SEI and UNESCO, Paris

Rodwell MJ, Rodwell DP, Folland CK (1999) Oceanic forcing of the wintertime North Atlantic Oscillation and European climate. Nature 398:320-323.

Rogers JC (1984) The association between the North Atlantic Oscillation and the Southern Oscillation in the northern hemisphere. Mon Weather Rev 112:1999-2015

Santos AMP, Borges MF, Groom S (2001) Sardine and horse mackerel recruitment and upwelling off Portugal. ICES J Mar Sci 58:589-596

Saunders MA, Qian B (2002) Seasonal predictability of the winter NAO from north Atlantic sea surface temperature. Geophys Res Lett 29:2049-2053 
Schiel DR, Steinbeck JR, Foster MS (2004) Ten years of induced ocean warming causes comprehensive changes in marine benthic communities. Ecology 85:1833-1839

Southward AJ, Hawkins SJ, Burrows MT (1995) Seventy years' observations of changes in distribution and abundance of zooplankton and intertidal organisms in the western English channel in relation to rising sea temperature. J Therm Biol 20:127-155

Speth P, Kohne A (1983) The relationship between sea surface temperatures and winds off northwest Africa and Portugal. Oceanogr Trop 18:69-80

Stenseth NC, Mysterud A, Ottersen G, Hurrell JW, Chan K-S, Lima M (2002) Ecological effects of climate fluctuations. Science 297:292-1296

Stenseth NC, Ottersen G, Hurrell JW, Mysterud A, Lima M, Chan KS, Yoccoz NG, Ådlandsvik B (2003) Studying climate effects on ecology through the use of climate indices: the North Atlantic Oscillation, El Niño Southern Oscilla- tion and beyond. Proc R Soc Lond B 270:2087-2096

Thomson DA, Lehner CE (1976) Resilience of a rocky intertidal fish community in a physically unstable environment. J Exp Mar Biol Ecol 22:1-29

Wanner H, Brönnimann S, Casty C, Gyalistras D, Luterbacher J, Schmutz C, Stephanson DB, Xoplaki E (2001) North Atlantic Oscillation - concepts and studies. Surv Geophys 22:321-382

Whitehead PJP, Bauchot ML, Hureau JC, Nielsen J, Tortonese EE (eds) (1984) Fishes of the north-eastern Atlantic and the Mediterranean, Vol I. UNESCO, Paris

Whitehead PJP, Bauchot ML, Hureau JC, Nielsen J, Tortonese EE (eds) (1986) Fishes of the north-eastern Atlantic and the Mediterranean, Vols II-III. UNESCO, Paris

Woehrling D, Lefebvre A, Le Fèvre-Lehoërff G, Delesmont R (2005) Seasonal and longer term trends in sea temperature along the French North Sea coast, 1975 to 2002. J Mar Biol Assoc UK 85:39-48

Appendix 1. Species observed during the survey and their biogeographic affinity group. See 'Materials and methods' for definitions of biogeographic groups

\begin{tabular}{|c|c|c|}
\hline Family & Species & Biogeographic group \\
\hline Rajidae & Raja undulata & Warm-temperate \\
\hline Myliobatidae & Myliobatis aquila & Tropical \\
\hline Muraenidae & Muraena helena & Warm-temperate \\
\hline Congridae & Conger conger & Temperate \\
\hline Clupeidae & Sardina pilchardus & Temperate \\
\hline Phycidae & $\begin{array}{l}\text { Ciliata mustela } \\
\text { Gaidropsarus mediterraneus } \\
\text { Gaidropsarus vulgaris } \\
\text { Phycis phycis }\end{array}$ & $\begin{array}{l}\text { Cold-temperate } \\
\text { Temperate } \\
\text { Cold-temperate } \\
\text { Warm-temperate }\end{array}$ \\
\hline Gadidae & $\begin{array}{l}\text { Pollachius pollachius } \\
\text { Trisopterus luscus }\end{array}$ & $\begin{array}{l}\text { Cold-temperate } \\
\text { Temperate }\end{array}$ \\
\hline Batrachoididae & Halobatrachus didactylus & Tropical \\
\hline Mugilidae & $\begin{array}{l}\text { Chelon labrosus } \\
\text { Liza aurata } \\
\text { Liza ramada } \\
\text { Mugil cephalus }\end{array}$ & $\begin{array}{l}\text { Temperate } \\
\text { Temperate } \\
\text { Temperate } \\
\text { Tropical }\end{array}$ \\
\hline Atherinidae & Atherina presbyter & Temperate \\
\hline Belonidae & Belone belone gracilis & Temperate \\
\hline Zeidae & Zeus faber & Eurythermic \\
\hline Syngnathidae & $\begin{array}{l}\text { Entelurus aequoraeus } \\
\text { Hippocampus hippocampus } \\
\text { Hippocampus ramulosus } \\
\text { Nerophis lumbriciformes } \\
\text { Syngnathus acus } \\
\text { Syngnathus typhle }\end{array}$ & $\begin{array}{l}\text { Cold-temperate } \\
\text { Warm-temperate } \\
\text { Warm-temperate } \\
\text { Cold-temperate } \\
\text { Temperate } \\
\text { Temperate }\end{array}$ \\
\hline Macroramphosidae & Macroramphosus scolopax & Oceanic \\
\hline Scorpaenidae & $\begin{array}{l}\text { Scorpaena notata } \\
\text { Scorpaena porcus }\end{array}$ & $\begin{array}{l}\text { Warm-temperate } \\
\text { Warm-temperate }\end{array}$ \\
\hline
\end{tabular}


Appendix 1 (continued)

\begin{tabular}{|c|c|c|}
\hline Family & Species & Biogeographic group \\
\hline Triglidae & $\begin{array}{l}\text { Trigloporus lastoviza } \\
\text { Aspitrigla obscura }\end{array}$ & $\begin{array}{l}\text { Eurythermic } \\
\text { Warm-temperate }\end{array}$ \\
\hline Cottidae & Taurulus bubalis & Cold-temperate \\
\hline Moronidae & Dicentrarchus labrax & Temperate \\
\hline Serranidae & $\begin{array}{l}\text { Serranus atricauda } \\
\text { Serranus cabrilla } \\
\text { Serranus hepatus }\end{array}$ & $\begin{array}{l}\text { Warm-temperate } \\
\text { Tropical } \\
\text { Warm-temperate }\end{array}$ \\
\hline Carangidae & $\begin{array}{l}\text { Trachurus mediterraneus } \\
\text { Trachurus picturatus } \\
\text { Trachurus trachurus } \\
\text { Seriola sp. }\end{array}$ & $\begin{array}{l}\text { Warm-temperate } \\
\text { Warm-temperate } \\
\text { Temperate } \\
\text { Oceanic }\end{array}$ \\
\hline Sparidae & $\begin{array}{l}\text { Boops boops } \\
\text { Diplodus annularis } \\
\text { Diplodus bellottii } \\
\text { Diplodus cervinus } \\
\text { Diplodus puntazzo } \\
\text { Diplodus sargus } \\
\text { Diplodus vulgaris } \\
\text { Oblada melanura } \\
\text { Pagellus acarne } \\
\text { Pagrus auriga } \\
\text { Pagrus pagrus } \\
\text { Sarpa salpa } \\
\text { Sparus aurata } \\
\text { Spondyliosoma cantharus }\end{array}$ & $\begin{array}{l}\text { Eurythermic } \\
\text { Warm-temperate } \\
\text { Warm-temperate } \\
\text { Warm-temperate } \\
\text { Tropical } \\
\text { Tropical } \\
\text { Warm-temperate } \\
\text { Tropical } \\
\text { Temperate } \\
\text { Tropical } \\
\text { Warm-temperate } \\
\text { Tropical } \\
\text { Warm-temperate } \\
\text { Temperate }\end{array}$ \\
\hline Centracanthidae & Spicara maena & Warm-temperate \\
\hline Mullidae & Mullus surmuletus & Temperate \\
\hline Pomacentridae & Chromis chromis & Tropical \\
\hline Labridae & $\begin{array}{l}\text { Centrolabrus exoletus } \\
\text { Coris julis } \\
\text { Ctenolabrus rupestris } \\
\text { Labrus bergylta } \\
\text { Labrus bimaculatus } \\
\text { Symphodus bailloni } \\
\text { Symphodus cinereus } \\
\text { Symphodus mediterraneus } \\
\text { Symphodus melops } \\
\text { Symphodus ocellatus } \\
\text { Symphodus roissali } \\
\text { Symphodus rostratus }\end{array}$ & $\begin{array}{l}\text { Cold-temperate } \\
\text { Temperate } \\
\text { Temperate } \\
\text { Cold-temperate } \\
\text { Temperate } \\
\text { Temperate } \\
\text { Warm-temperate } \\
\text { Warm-temperate } \\
\text { Cold-temperate } \\
\text { Warm-temperate } \\
\text { Warm-temperate } \\
\text { Warm-temperate }\end{array}$ \\
\hline Ammodytidae & $\begin{array}{l}\text { Ammodytidae n. id. } \\
\text { Hyperoplus lanceolatus }\end{array}$ & $\begin{array}{l}\text { Oceanic } \\
\text { Cold-temperate }\end{array}$ \\
\hline Trachinidae & $\begin{array}{l}\text { Echiichthys vipera } \\
\text { Trachinus draco }\end{array}$ & $\begin{array}{l}\text { Temperate } \\
\text { Temperate }\end{array}$ \\
\hline Tripterygiidae & Tripterygion delaisi & Warm-temperate \\
\hline Blenniidae & $\begin{array}{l}\text { Coryphoblennius galerita } \\
\text { Lipophrys canevai } \\
\text { Lipophrys pholis } \\
\text { Lipophrys trigloides } \\
\text { Parablennius gattorugine } \\
\text { Parablennius incognitus } \\
\text { Parablennius pilicornis } \\
\text { Parablennius rouxi } \\
\text { Parablennius sanguinolentus }\end{array}$ & $\begin{array}{l}\text { Warm-temperate } \\
\text { Warm-temperate } \\
\text { Temperate } \\
\text { Warm-temperate } \\
\text { Warm-temperate } \\
\text { Warm-temperate } \\
\text { Tropical } \\
\text { Warm-temperate } \\
\text { Warm-temperate }\end{array}$ \\
\hline Clinidae & Clinitrachus argentatus & Warm-temperate \\
\hline Gobiesocidae & $\begin{array}{l}\text { Apletodon dentatus } \\
\text { Diplecogaster bimaculata bimaculata } \\
\text { Lepadogaster candollii } \\
\text { Lepadogaster lepadogaster }\end{array}$ & $\begin{array}{l}\text { Warm-temperate } \\
\text { Temperate } \\
\text { Warm-temperate } \\
\text { Warm-temperate }\end{array}$ \\
\hline
\end{tabular}


Appendix 1 (continued)

\begin{tabular}{|c|c|c|}
\hline Family & Species & Biogeographic group \\
\hline Callionymidae & $\begin{array}{l}\text { Callionymus lyra } \\
\text { Callionymus reticulatus }\end{array}$ & $\begin{array}{l}\text { Temperate } \\
\text { Temperate }\end{array}$ \\
\hline Gobiidae & $\begin{array}{l}\text { Gobius xanthocephalus } \\
\text { Gobius cobitis } \\
\text { Gobius cruentatus } \\
\text { Gobius niger } \\
\text { Gobius paganellus } \\
\text { Gobius gasteveni } \\
\text { Gobiusculus flavescens } \\
\text { Pomatoschistus marmoratus } \\
\text { Pomatoschistus pictus } \\
\text { Thorogobius ephippiatus }\end{array}$ & $\begin{array}{l}\text { Warm-temperate } \\
\text { Warm-temperate } \\
\text { Warm-temperate } \\
\text { Temperate } \\
\text { Warm-temperate } \\
\text { Warm-temperate } \\
\text { Cold-temperate } \\
\text { Warm-temperate } \\
\text { Temperate } \\
\text { Temperate }\end{array}$ \\
\hline Scombridae & $\begin{array}{l}\text { Scomber japonicus } \\
\text { Sarda sarda }\end{array}$ & $\begin{array}{l}\text { Tropical } \\
\text { Eurythermic }\end{array}$ \\
\hline Bothidae & $\begin{array}{l}\text { Arnoglossus thori } \\
\text { Arnoglossus imperialis } \\
\text { Bothus podas podas }\end{array}$ & $\begin{array}{l}\text { Warm-temperate } \\
\text { Tropical } \\
\text { Tropical }\end{array}$ \\
\hline Scophthalmidae & $\begin{array}{l}\text { Phrynorhombus regius } \\
\text { Scophthalmus rhombus } \\
\text { Zeugopterus puntactus }\end{array}$ & $\begin{array}{l}\text { Warm-temperate } \\
\text { Warm-temperate } \\
\text { Cold-temperate }\end{array}$ \\
\hline Soleidae & $\begin{array}{l}\text { Buglossidium luteum } \\
\text { Monochirus hispidus } \\
\text { Solea vulgaris } \\
\text { Solea senegalensis } \\
\text { Synaptura lusitanica }\end{array}$ & $\begin{array}{l}\text { Warm-temperate } \\
\text { Tropical } \\
\text { Temperate } \\
\text { Warm-temperate } \\
\text { Tropical }\end{array}$ \\
\hline Balistidae & Balistes carolinensis & Eurythermic \\
\hline Tetraodontidae & Sphoeroides marmoratus & Tropical \\
\hline Molidae & Mola mola & Oceanic \\
\hline
\end{tabular}

Editorial responsibility: Otto Kinne (Editor-in-Chief), Oldendorf/Luhe, Germany
Submitted: January 6, 2006; Accepted: October 2, 2006 Proofs received from author(s): May 20, 2007 